The Journal of Animal \& Plant Sciences, 31(1): 2021, Page: 273-279

ISSN (print): 1018-7081; ISSN (online): 2309-8694

\title{
SUPPLEMENTATION OF PROBIOTIC (Bacillus subtilis) FOR IMPROVEMENT OF GROWTH PERFORMANCE AND DIGESTIVE ENZYMES ACTIVITY OF PUNTIUS JAVANICUS UNDER INTENSIVE AQUACULTURE SYSTEM
}

\author{
D. Rachmawati ${ }^{*}$ I. Samidjan, S. Windarto and Asep A. Prihanto \\ Aquaculture Department, Faculty of Fisheries and Marine Science, Diponegoro University, Jl. Prof. H. Soedarto SH, \\ Tembalang, Semarang, 50275, Central Java, Indonesia \\ Dept. Fishery Product Technology, Faculty of Fisheries and Marine Science, Brawijaya University, Jl. Veteran, Malang, \\ 65145, East Java, Indonesia \\ Corresponding Author's email: dianarachmawati1964@gmail.com
}

\begin{abstract}
The experiment was conducted to examine effects of different doses of $B$. subtilis probiotic supplementation in feed on protein digestibility, growth and activity of digestive enzymes of $P$. javanicus on intensive farming system. $P$. javanicus fingerlings used as test animals. The treatments were B. subtilis probiotic on feed. Those were treatments A $\left(0 \mathrm{CFU} \mathrm{g}^{-1}\right.$ feed), B ( $0.75 \times 10^{7} \mathrm{CFU} \mathrm{g}^{-1}$ feed $), \mathrm{C}\left(1.50 \times 10^{7} \mathrm{CFU} \mathrm{g}^{-1}\right.$ feed $)$ and $\mathrm{D}\left(2.25 \times 10^{7} \mathrm{CFU} \mathrm{g}^{-1}\right.$ feed $)$. Observed parameters were protein digestibility $\left(A D C_{P}\right)$, efficiency of feed utilization $(E F U)$, ratio of feed conversion (FCR), ratio of protein efficiency (PER), relative growth rate (RGR), survival rate (SR), digestive enzymes activity and quality of water. The result showed that supplementation of $B$. subtilis on feeds significantly $(\mathrm{P} \leq 0.05)$ affected $A D C_{P}, E F U, F C R, P E R, R G R$, SR and digestive enzyme activities. The experiment was conducted under the viable water quality. The optimum supplementation dose of $B$. subtilis was $1.50 \times 107 \mathrm{CFU} \mathrm{g}{ }^{-1}$ feed resulted in the highest value of $\mathrm{ADC}_{\mathrm{P}}(75.28 \%)$, EFU (74.06\%), FCR (1.52), PER (3.78), RGR (3.23\% / day), SR (98.33\%) and digestive enzymes (protease and amylase) activities were $4.32,3.42 \mathrm{U} \mathrm{g}^{-1}$ protein, respectively.
\end{abstract}

Key words: probiotic, Bacillus subtilis, growth performance, Puntius javanicus.

https://doi.org/10.36899/JAPS.2021.1.0214

Published online August 26, 2020

\section{INTRODUCTION}

The java barb (Puntius javanicus) is one of the potential Indonesian native fish and one of the fishery commodities favored by the community. This has led to an increase in java barb production so that market demand can be fulfilled by implementing the intensive fish culture. The success of intensive java barb cultivation is determined by the availability of quality feed. Quality feed is an important factor in intensive aquaculture and it is the largest cost in intensive fish production processes (Tawwab et al., 2010), however, quality feed should not only contain nutrients that meet fish requirements, but also make fish resistant to the disease so that it remains healthy and can increase growth (Goda et al., 2012). Therefore, various efforts need to be made to improve the quality of feed. One of these efforts is by adding probiotics into the feed.

Probiotics are living microbes when given in sufficient quantities can bring about healthier state of the host and can increase balance of microbes in the digestive tract (Nayak, 2010). Nowadays, the main strategy used is the probiotics supplementation into fish feed that can improve growth (Ghosh et al., 2003). Furthermore, Iribarren et al., (2012) expressed that the probiotics supplementation into feed can increase growth and efficiency of feed utilization so that it can reduce the accumulation of waste in the water. The probiotics use in fish aquaculture activities to boost growth and increase the ability of resistance to disease has been reported by Nandi et al., (2017). The rapid probiotics implementation in fish aquaculture was reported by Gatesoupe, (1999) moreover Rengpipat et al. (2000) disclosed that proper use of probiotics in aquaculture increased the number of microbes in the intestine, and increased feed absorption, thereby increasing fish growth rates and decreasing ratio of feed conversion (FCR) (Wang et al., 2005). Gatesoupe, (2008) also stated that probiotics can improve the digestion of fish by producing digestive enzymes in the intestine leading to increased growth performance. The addition of probiotics into feed can improve the performance of growth and immune response that has been reported in Oreochromis niloticus (Wang et al. $2008^{\mathrm{a}}$ ) and Halibut larvae (Bjornsdottir et al., 2010); survival rate and activity of digestive enzyme in Penaeus vannamei larvae (Zhou et al., 2009); to increase feed conversion, growth and increase weight in salmon (Taoka et al., 2006; Bagheri et al., 2008; Wang et al., 2008b).

One of bacteria believed to be able to improve the quality of feed and the fish immune system is Bacillus subtilis which is spore-forming bacterium generally 
apllied as a probiotic. B. subtilis can raise survival and growth of cultivated fish (Gomez-Gil et al., 2008) and has the ability to secrete protease, lipase and amylase (Wang et al., 2008 b). Some studies on Bacillus subtilis supplementation into feed for different species included Macrobrachium rosenbergii (Keysami et al., 2007), Litopenaeus vannamei (Liu et al., 2009, 2010; Tseng et al., 2009), Labeo rohita (Kumar et al., 2006; Nandi et al., 2017), Oncorhynchus myskiss (Adineh et al., 2013), and Sparus aurata (Arig et al., 2013).

Research on B. subtilis probiotic supplementation in java barb feed has not yet been done. Based on this reason, the study was conducted to improve protein digestibility, growth and immune response of java barb. The objectives of the study were to examine probiotic supplementation effects of $B$. subtilis in the feed on protein digestibility, growth and activity of digestive enzymes of java barb on intensive aquaculture system.

\section{MATERIALS AND METHODS}

Samples: There were 2,400 samples of Java barb fingerlings with the weight ranging from 3.28 to $3.40 \mathrm{~g}$. The fish were obtained from the Freshwater Hatchery and Cultivation Work Unit, Ngrajek, Magelang, Central Java, Indonesia. The fish fingerling used had the uniformed weight, healthy, and there were no deformities which were then acclimatized for 2 weeks and fasted one day before the study (Rachmawati et al., 2017). Before the implementation of the study, java barb fingerlingwere weighed to determine the initial weight. The study has been conducted for 60 days. The weighing process to determine the weight gain of java barb was done every week.

Cultivation Preparation: The dimension of cultivation nets was $1 \times 1 \times 1 \mathrm{~m}^{3}$. There were 16 pieces which were placed in a $6 \times 10 \mathrm{~m}^{2}$ ground pond with a water level of $1.25 \mathrm{~m}$. Java barb cultivation in this study was carried out intensively with fingerling stocking densities of 150 fish / $\mathrm{m}^{2}$. For protein digestibility analysis, a cultivation container in the form of a fiber tub with a volume of 500 liters of water was used as a place to accommodate fish feces. Collection of fish feces was done every day a few hours after the fish were fed. Fish feces was collected, then filtered, put into sample bottles and stored in the refrigerator.

Bacillus subtilis: Bacillus subtilis was retrieved from the digestive system of Clarias gariepinus which was obtained from the Division of Fish Health Management of Freshwater Hatchery and Cultivation Work Unit, Ngrajek, Magelang, Central Java, Indonesia. B. subtilis culture was prepared by following the method adopted by Kumar et al. (2006) that pure B. subtilis culture was inoculated into a $500 \mathrm{~mL}$ volume cone tube filled with broth. The bacterium has been incubated for 24 hours at $30^{\circ} \mathrm{C}$ in an incubator. Then it was centrifuged at $10,000 \mathrm{~g}$ for 20 minutes at $4^{\circ}$ Celcius and the floating waste was removed, while the sediment was diluted in saline based phosphate (PBS; pH 7.2). Furthermore, the measurement of the mixture was done using a technique of spread plate on agar nutrient, was fertilized for 24 hours at $30^{\circ} \mathrm{C}$. The suspension of pure bacteria was reserved at $4^{\circ} \mathrm{C}$ and used according to the treatments.

Research Methods and Feed Preparation: The experiment was laid out under completely randomized design. There were 4 treatments and 4 replicates per treatment. The treatment in this study was supplementation of different doses of $B$. subtilis probiotics in the feed. This research was carried out in the Freshwater Hatchery and Cultivation Work Unit, Ngrajek, Magelang, Central Java, Indonesia from March to June 2018.

The feed used was artificial feed with $30 \%$ protein content supplemented with probiotics B. subtilis by spraying on feed according to the doses of treatment $\mathrm{A}$ (0 CFU g ${ }^{1}$ feed $), B\left(0.75 \times 10^{7} \mathrm{CFU} \mathrm{g}^{1}\right.$ feed $), \mathrm{C}(1.50 \mathrm{x}$ $10^{7} \mathrm{CFU} \mathrm{g}^{1}$ feed $)$ and $\mathrm{D}\left(2.25 \times 10^{7} \mathrm{CFU} \mathrm{g}^{1}\right.$ feed $)$ and added $0.5 \% \mathrm{Cr}_{2} \mathrm{O}_{3}$ for protein digestibility analysis. The dose determination of $B$. subtilis probiotics in this study was modified findings by Kumar et al., (2006) who reported that $B$. subtilis probiotic doses of $1.5 \times 10^{7} \mathrm{CFU}$ $\mathrm{g}^{1}$ feed showed the best growth in Labeo rohita. The feed fingerlinggiven during the study was $5 \% /$ biomass weight / day with the feeding frequency of three times a day.

Digestive Enzymes Analysis: Analysis of the digestive enzymes activity using crude extract of the digestive tract of java barb referred to the Sandeepa and Ammani (2015), while the measurement of total protein activity referred to the method of Brandford (1976). Meanwhile protease activity and amylase activity referred to Anson's method (1938) and Rick and Stegbauer's methods (1984), respectively.

Parameters: The parameters observed included protein digestibility (ADCP) using the method of Fenucci (1981), efficiency of feed utilization (EFU), ratio of feed conversion (FCR) and ratio of protein efficiency (PER) using the Tacon's method (1995), relative growth rate (RGR) and survival rate (SR) using the NRC (1993) method, digestive enzyme activity, and water quality. The observed parameters were:

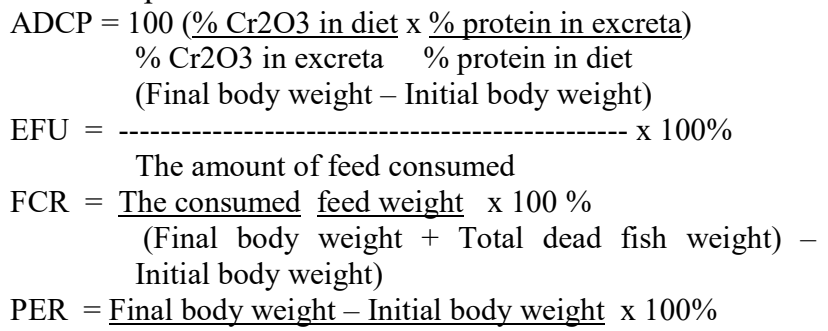


The consumed feed weight $x$ Protein content of feed

RGR $=$ Final body weight - Initial body weight $\times 100 \%$ Initial body weight $x$ Time experiment

SR $=$ Final body count $\times 100 \%$

Initial body count

Water quality: Observed parameters of water quality included temperature, $\mathrm{pH}$ and DO. They were enumerated daily using Water Quality Checker and ammonia. The measurement was conducted at the starting time, intermediate and at the end of the study using the APHA method (1995).

Statistical analysis: The observed parameter data (ADCP, EFU, FCR, PER, RGR, SR and digestive enzyme activity) were analyzed using ANOVA test. If the ANOVA analysis had significantly high $(\mathrm{P} \leq 0.01)$ or significantly $(\mathrm{P} \leqq 0.05)$ influenced on those parameters, they were followed by Duncan's multiple region test to find out the mean difference among treatments (Steel et al., 1996). Parameters of water quality data were descriptively analyzed.

\section{RESULTS AND DISCUSSION}

The findings of digestive enzymes and the parameters of water quality were displayed in the Table 1, 2 and 3.

Table 1. Initial weight, final weight, ADCp, EFU, FCR, RGR, PER and SR of Java barb fingerling during the study.

\begin{tabular}{lcccc}
\hline \multirow{2}{*}{ Experiment Data } & \multicolumn{4}{c}{ Treatments } \\
\cline { 2 - 5 } & \multicolumn{1}{c}{ A } & B & C & D \\
\hline Initial weight $(\mathrm{g})$ & $3.34 \pm 0.06$ & $3.28 \pm 0.04$ & $3.40 \pm 0.03$ & $3.36 \pm 0.01$ \\
Final weight(g) & $28.19 \pm 0,04^{\mathrm{c}}$ & $34.53 \pm 0,02^{\mathrm{b}}$ & $38.69 \pm 0,05^{\mathrm{b}}$ & $45.24 \pm 0,03^{\mathrm{a}}$ \\
ADC $_{\mathrm{P}}$ & $52.63 \pm 0.03^{\mathrm{c}}$ & $62.14 \pm 0.07^{\mathrm{b}}$ & $75.28 \pm 0.06^{\mathrm{a}}$ & $63.89 \pm 0.07^{\mathrm{b}}$ \\
EFU (\%) & $45.19 \pm 0.56^{\mathrm{c}}$ & $63.26 \pm 0.86^{\mathrm{b}}$ & $74.06 \pm 0.68^{\mathrm{a}}$ & $65.63 \pm 0.73^{\mathrm{b}}$ \\
FCR & $2.58 \pm 0.16^{\mathrm{c}}$ & $2.05 \pm 0.06^{\mathrm{b}}$ & $1.52 \pm 0.02^{\mathrm{a}}$ & $1.98 \pm 0.14^{\mathrm{b}}$ \\
RGR (\%) & $1.87 \pm 0.24^{\mathrm{c}}$ & $2.36 \pm 0.21^{\mathrm{b}}$ & $3.78 \pm 0.14^{\mathrm{a}}$ & $2.64 \pm 0.74^{\mathrm{b}}$ \\
PER & $1.56 \pm 0.13^{\mathrm{c}}$ & $2.21 \pm 0.17^{\mathrm{b}}$ & $3.23 \pm 0.16^{\mathrm{a}}$ & $2.37 \pm 0.13^{\mathrm{b}}$ \\
SR (\%) & $78.33 \pm 2.45^{\mathrm{c}}$ & $88.33 \pm 2.23^{\mathrm{b}}$ & $98.33 \pm 2.32^{\mathrm{a}}$ & $88.33 \pm 2.54^{\mathrm{b}}$ \\
\hline
\end{tabular}

Note different superscripts of mean values show a significant difference $(\mathrm{P} \leqq 0.05)$

Table 2. Digestive enzymes values in the digestive system of Java barb fed with enrichment of $B$. subtilis probiotics during the study.

\begin{tabular}{|c|c|c|c|c|}
\hline \multirow{2}{*}{ Activity (U g-1 protein) } & \multicolumn{4}{|c|}{ Treatments } \\
\hline & $\mathbf{A}$ & B & $\mathbf{C}$ & D \\
\hline Total protein & $2.26 \pm 0,13^{\mathrm{d}}$ & $3.23 \pm 0,16^{\mathrm{c}}$ & $5.28 \pm 0,18^{a}$ & $4.18 \pm 0,25^{\mathrm{a}}$ \\
\hline Protease & $1.65 \pm 0,15^{\mathrm{c}}$ & $1.83 \pm 0.21^{\mathrm{c}}$ & $4.32 \pm 0.27^{\mathrm{a}}$ & $2.75 \pm 0.26^{\mathrm{b}}$ \\
\hline Amylase & $1.48 \pm 0,02^{\mathrm{c}}$ & $2.08 \pm 0,03^{b}$ & $3.42 \pm 0.17^{\mathrm{a}}$ & $2.23 \pm 0.14^{\mathrm{b}}$ \\
\hline
\end{tabular}

Note: different superscripts of mean values show a significant difference $(\mathrm{P} \leqq 0.05)$

Table 3. Water quality parameters during the study.

\begin{tabular}{lcccc}
\hline \multirow{2}{*}{ Treatment } & \multicolumn{4}{c}{ Water Quality } \\
\cline { 2 - 5 } & Temperature $\left.\mathbf{(}^{\mathbf{0}} \mathbf{C}\right)$ & $\mathbf{p H}$ & $\mathbf{D O}(\mathbf{m g} / \mathbf{l})$ & $\mathbf{N H}_{\mathbf{3}}(\mathbf{( \% )})$ \\
\hline A & $25-30$ & $7.21-7.43$ & $3.68-4.97$ & $0.002-0.004$ \\
B & $25-30$ & $7.06-7.52$ & $3.74-4.78$ & $0.002-0.004$ \\
C & $25-30$ & $7.31-7.48$ & $3.63-4.59$ & $0.002-0.004$ \\
D & $25-30$ & $7.29-7.37$ & $3.72-4.68$ & $0.002-0.004$ \\
Feasibility & $14-38^{*}$ & $6.50-8.5^{*}$ & $>2^{*}$ & $\leq 0.1^{*}$ \\
\hline
\end{tabular}

Note : ${ }^{*}$ Boyd (2003)

The results of observations of water quality parameters in Table 3 showed that the parameters of water quality during the study were still within the feasible range values according to the reference, it concluded that it was suitable for Java barb cultivation.

The results of the analysis of the variance of $B$. subtilis probiotic supplementation of the different doses had significantly $(\mathrm{P} \leqq 0.05)$ influenced on digestibility of protein (ADCp) of Java barb fish fingerling (Puntius javanicus). Java barb fed with $B$. subtilis probiotic supplementation (0.75 - $2.25 \times 10^{7} \mathrm{CFU} \mathrm{g}^{-1}$ feed) had higher ADCP values than without supplementation (0 CFU $\mathrm{g}^{-1}$ feed). It was suspected that $B$. subtilis has the ability to produce protease enzymes so that the digestive 
activity of the protein runs optimally. B. subtilis probiotics produce protease enzymes that can increase protein digestion activities (Verschuere et al., 2000; Ziaei-Nejad et al., 2006; Jafaryan et al., 2011). The highest ADCP value was obtained from Java barb fed C (1.50 $\times 10^{7} \mathrm{CFU} \mathrm{g}^{-1}$ feed), this was thought to be an effective dose for $B$. subtilis to generate protease enzymes in the digestive tract of Java barb fingerling so that digestibility of feed protein runs maximum. This condition was supported by the results of the analysis of digestive enzymes on the observation of total proteins and proteases in the digestive tract of Java barb fingerlingfed $\mathrm{C}$ (Table 2) having the highest total protein and protease activity of $\left(5.28 \mathrm{U} \mathrm{g}^{-1}\right.$ protein and $4.32 \mathrm{U} \mathrm{g}^{-1}$ protein) compared to feed $\mathrm{D}\left(4.18 \mathrm{U} \mathrm{g} \mathrm{g}^{-1}\right.$ protein and 2.75 $\mathrm{U} \mathrm{g}^{-1}$ protein), B (3.23 $\mathrm{U} \mathrm{g}^{-1}$ protein and $1.83 \mathrm{U} \mathrm{g}^{-1}$ protein) and $\mathrm{A}$ (2.26 $\mathrm{U} \mathrm{g}^{-1}$ protein and $1.65 \mathrm{U} \mathrm{g}^{-1}$ protein).

Java barb ( $P$. javanicus) fed with $B$. subtilis probiotic supplementation in the treatments $\mathrm{B}, \mathrm{C}$ and $\mathrm{D}$ (0.75 - $2.25 \times 10^{7} \mathrm{CFU} \mathrm{g}^{-1}$ feed) had a higher EFU value (63.26 - 74.06\%) compared to without supplementation in the treatment A $(45.19 \%)$. This was supported by the results of research on observations of Java barb fingerling digestive enzymes (Table 2) which showed that feed with enrichment of $B$. subtilis probiotics can increase the activity of digestive enzymes of Java barb, therefore the efficiency of feed utilization can be maximized. The results of these studiesindicated that supplementation of $B$. subtilis probiotic in the feed can improve the efficiency of utilization of Java barb feed. This was confirmed by the opinion of El-Haroun et al. (2006) which stated that the addition of probiotics into the feed caused fish to be able to utilize nutrients more efficiently so as to improve the efficiency of feed utilization. Furthermore Lara-Flores et al. (2003) stated that the probiotics supplementation into the feeds could result in a higher efficiency of feed utilization compared to without the addition of probiotics. Moreover, Merrifield et al. (2010) suggested that the probiotics supplementation into the feed of tilapia and other species led to better nutrient absorption and efficiency of feed utilization. The findings of the same study were reported by Bogut et al., (1998) on Cyprinus carpio, Wang, (2007) and Zhou et al. (2009) on Litopenaeus vannamei and $\mathrm{Wu}$ et al. (2012) on Ctenopharyngodon idella.

The FCR value of Java barb fed with $B$. subtilis probiotic supplementation (0.75-2.25 x $10^{7} \mathrm{CFU} \mathrm{g}^{-1}$ feed) decreased further by 2.05 - 1.52 compared to no additions $(0 \% / \mathrm{kg}$ of feed) which was 2.58 . The findings showed that B. subtilis supplementation in feed can reduce FCR due to protein digestibility and efficiency of feed utilization increases so that the feed conversion ratio decreases. Taoka et al. (2006), Bagheri et al. (2008), Wang et al. $\left(2008^{\mathrm{a}}\right)$ reported that the B. subtilis probiotic supplementation in feed could reduce the feed conversion ratio of Salmon. Java barb fingerling fed as in the treatment $\mathrm{C}\left(1.50 \times 10^{7} \mathrm{CFU} \mathrm{g}^{-1}\right.$ feed $)$ resulted in the lowest FCR value indicated by the highest protein digestibility and efficiency of feed utilization $(75.28 \%$ and $74.06 \%)$ compared to treatments $\mathrm{D}(63.89 \%$ and $65.63 \%), \mathrm{B}(62.14 \%$ and $63.26 \%)$ and $\mathrm{A}(52.63 \%$ and $45.19 \%$ ). The results of similar studies were reported on Cyprinus carpio (Wang and $\mathrm{Xu}, 2006$ ), Litopenaeus vannamei (Wang, 2007; Zhou et al., 2009), Ctenopharyngodon idella, (Wu et al., 2012), S. aurata (Salinas et al. , 2005, 2006; Díaz-Rosales et al., 2006; Suzer et al., 2008; Avella et al., 2010).

The RGR value of Java barb fed with $B$. subtilis supplementation was $0.75-2.25 \times 10^{7} \mathrm{CFU} \mathrm{g} \mathrm{g}^{-1}$ feed increased from $2.38-3.78 \%$ / day compared to without supplementation ( 0 CFU $\mathrm{g}^{1}$ feed) of $1.87 \%$ / day. The findings were the same as with the opinion of Merrifield et al. (2010) which stated that probiotic addition in feed increases fish growth effectively. Lara-Flores et al. (2003) reported that the probiotics supplementation into the feed produced higher growth compared to without the addition of probiotics. The results of the study by Taoka et al. (2006), Bagheri et al. (2008), Wang et al. (2008 reported that the $B$. subtilis probiotic addition in the feed can increase the growth of Salmon. Java barb fed as in the treatment $\mathrm{C}\left(1.50 \times 10^{7} \mathrm{CFU} \mathrm{g}^{-1}\right.$ feed $)$ had the highest RGR value of $3.78 \%$ / day followed by the treatments D (2.64\% / day), B (2.36\% / day) and A (1.87\% / day ). The Java barb fed as in the treatment $\mathrm{C}$ had the highest RGR value, it was assumed that the dose of B. subtilis is $1.50 \mathrm{x}$ $10^{7} \mathrm{CFU} \mathrm{g}^{-1}$ feed was an effective dose of $B$. subtilis in increasing growth because at that dose the digestive enzymes in digestion of Java barb fingerling run optimally. The statement was supported by observations of digestive enzyme activity in Table 2 which showed that the highest digestive enzyme (total protein, protease and amylase) activity was obtained from Java barb fingerlingfed in the treatment $\mathrm{C}$ compared to other treatments. In addition, Java barb fed as in the treatment $\mathrm{C}$ had the highest ADCp and EFU values $(75.28 \%$ and $74.06 \%)$ compared to treatments D $(63.89 \%$ and $65.63 \%), \mathrm{B}(62.14 \%$ and $63.26 \%)$ and $\mathrm{A}(52.63 \%$ and $45.19 \%$ ). The results of a similar study were reported by Wang, (2007); Zhou et al. (2009); Wu et al. (2012); Macey and Coyne, (2005), Wang et al. (2005), Wang and $\mathrm{Xu}$, (2006).

Java barb fingerling fed with $B$. subtilis supplementation of $0.75-2.25 \times 10^{7} \mathrm{CFU} \mathrm{g}^{-1}$ feed had a higher PER value than without supplementation (0 CFU $\mathrm{g}^{-1}$ feed). The findings revealed that the $B$. subtilis addition in the feed could increase protein digestibility and the number of protease enzymes in the digestive tract of Java barb fingerling, so that the formation of proteins of the Java barb increased. Lara-Flores et al. (2003) suggested that the addition of probiotics into the feed can boost digestibility of protein and protein efficiency which causes an increase in fish protein. The same results were 
occured on sea bass (Tovar et al., 2010), Cyprinus carpio (Bogut et al., 1998), Litopenaeus vannamei (Wang, 2007; Zhou et al. 2009) and Ctenopharyngodon idella (Wu et al., 2012).

The results of the variance analysis disclosed that the $B$. subtilis probiotic supplementation at different doses in the feed had significantly $(\mathrm{P} \leq 0.05)$ affected on the Java barb fingerling survival. The findings of this study indicated that the survival rate of Java barb rised with the supplementation of $B$. subtilis probiotic in the feed. It was suspected that $B$. subtilis probiotics can increase the body's resistance so as to improve the Java barb survival. Taoka et al. (2006), Bagheri et al. (2008), Wang et al. $\left(2008^{\mathrm{a}}\right)$ reported that the B. subtilis probiotics addition in the feed can improve the survival of Salmon. The findings of a similar research were also reported by Wang, (2007), Avella et al. (2010), WenYing et al. (2010) and Mohapatra et al. (2012).

The findings of the variance analysis revealed that the different dosages of $B$. subtilis probiotic supplementation in the feed had significantly $(\mathrm{P} \leq 0.05)$ influenced on the digestive enzymes activity of Java barb. Observations of digestive enzyme activities (Table 2) showed higher levels of digestive enzyme activities (total protein, protease, amylase) obtained on Java barb fed with $B$. subtilis probiotic supplementation (treatments B, $\mathrm{C}$ and D) compared to feed without supplementation (treatment A). The results of the same study was reported by Ziaei-Nejad et al. (2006). They suggested that the activity of digestive enzymes of shrimp (Fenneropenaeus indicus) fed with supplementation with Bacillus sp. was higher than those of without supplementation. The observation of the digestive enzyme activity of Java barb fingerling in the treatment $\mathrm{C}$ had a higher value of digestive enzyme activity than those of the treatments $\mathrm{D}$, $\mathrm{B}$ and A. This was presumed to be a dose of probiotic $B$. Subtilis of $1.50 \times 10^{7} \mathrm{CFU} \mathrm{g}^{-1}$ feed was the best dose to boost the amount of microbes in the intestine digestive tract of Java barb fingerling. This finding was the same as with the study result of Rengpipat et al. (2000) which stated that the right dose of probiotics in the feed can increase the number of microbes in the intestine so that the enzymes activity in the digestive system increases.

Conclusion: Supplementation of B. subtilis into feed increased protein digestibility, growth and digestive enzymes activity of Java barb ( $P$. javanicus) which was cultured in intensive aquaculture system. The dose of $1.50 \times 10^{7} \mathrm{CFU} \mathrm{g}^{-1}$ feed was the best dose of B. subtilis supplementation in the feed of Java barb (P. javanicus).

Acknowledgment: The author would like to thank the Head of the Freshwater Hatchery and Cultivation Work Unit, Ngrajek, Magelang, Central Java, Indonesia for providing facilities and infrastructures during the research.

\section{REFERENCES}

Adineh, H., H. Jafaryan, J. Sahandi and M. Alizadhe (2013). Effect of Bacillus spp. Probiotic on Growth and Feeding Performance of Rainbow Trout (Oncorhynchus myskiss) Larvae. J. Vet. Med. 16: 29-36.

Anson M. L (1938). The estimation of pepsin, trypsin, papain, and cathepsin with hemoglobin. J. Gen Physiol. 22:79-89.

Arıg, N., C. Suzer, A. Gökvardar, F. Başaran, D. Çoban, S. Yıldırım, H. O. Kamacı, K. Fırat and Ş. Saka (2013). Effects of Probiotic (Bacillus sp.) Supplementation during Larval Development of Gilthead Sea Bream (Sparus aurata, L.). Turk J Fish Aquat Sc. 13: 407-414.

APHA (1995). Standard Methods for the Examination of Water and Wastewater. American Public Health Association Washington. D.C.185P.

Avella, M.A., G. Gioacchini, O. Decamp, P. Makridis, C. Bracciatelli, and O. Carnevali (2010). Application of multi-species of Bacillus in sea bream larviculture. Aquaculture. 305:12-19.

Bagheri, T., S.A. Hedayati, V. Yavari, M. Alizade,A. Farzanfar (2008). Growth, survival and gut microbial load of rainbow trout (Onchorhynchus mykiss) fry given diet supplemented with probiotic during the two months of first feeding. J. Fish Aquat Sci. 8: 43-48.

Bjornsdottir, R., E.G. Karadottir, J. Johannsdottir, E.E. Thorarinsdottir, H. Smaradottir, S. Sigurgisladottir and B.K. Gudmundsdottir (2010). Selection of bacteria and the effects of bacterial treatment of Atlantic halibut (Hippoglossus hippoglossus L.) eggs and larvae. Aquaculture. 302: 219-227.

Bogut, I., Z. Milakovic, Z. Bukvic, S. Brkic and R. Zimmer (1998). Influence of probiotic Streptococcus faecium M74 on growth and content of intestinal microflora in carp Cyprinus carpio. Czech. J. Anim. Sci. 43: 231-235.

Bradford, M.M. (1976). A rapid and sensitive method for the quantitation of microgram quantities of protein utilizing the principle of protein-dye binding. J. Anal Biochem. 72: 248-254.

Díaz-Rosales, P., I. Salinas, A. Rodríguez, A. Cuesta, M. Chabrillón, M.C. Balebona, M.Á. Morinigo, M.Á. Esteban and J. Meseguer ( 2006). Gilthead seabream (Sparus aurata, L.) innate immune response after dietary administration of heatinactivated potential probiotics. Fish Shellfish Immunol. 20: 482-492.

El-Haroun, E.R., S.A.M. Goda and M.A.K. Chowdury (2006). Effect of dietary probiotic Biogen $\AA$ supplementation as a growth promoter on growth performance and feed utilization of Nile 
tilapia Oreochromis niloticus (L.). Aquac Res. 37: 1473-1480.

Fenucci, J.L. (1981). Studies on The Nutrition of Marine Shrimp of The Penaeus Faculty of Department of Biology, University of Houston, Houston, Texas, USA (Ph D Thesis).

Gatesoupe, F. J. (1999). The use of probiotics in aquaculture. Aquaculture, 180: 147-165.

Gatesoupe, F.J. (2008). Updating the importance of lactic acid bacteria in fish farming: natural occurrence and probiotic treatments. J. Mol Microbiol Biotechnol. 14: 107-114.

Ghosh, K., S.K. Sen and A.K. Ray (2003). Supplementation of an isolated fish gut bacterium, Bacillus circulans, in formulated diets for rohu, Labeo rohita, fingerlings. J. Aquacult-Bamid. 55: 13-21.

Goda, A.M.A., H.A.H.H. Mabrouk, M.A.E. Wafa and T.M. El-Afifi (2012). Effect of Using Baker's Yeast and Exogenous Digestive Enzymes as Growth Promoters on Growth, Feed Utilization and Hematological Indices of Nile Tilapia, Oreochromis niloticus Fingerling. J. of Agric Sci Tech. 2: 15-28.

Gomes, L.C., R.P. Brinn, J.L. Marcon, L.A. Dantas, F.R. Brandao, J.S. Abreu, D.M.M Comb, B. Baldiser-otto (2008). Using Efinol L during transportation of Marbled hatchetfish, Carnegiella strigata (Günther). Aquac Res, 39: 1292-1298.

Iribarren, D., P. Dagá, M.T. Moreira, G. Feijoo (2012). Potential environmental effects of probiotics used in aquaculture. Aquacult Int, 20: 779-789.

Jafaryan, H., M.M. Taati, M. and Jafarzadeh (2011). The enhancement of growth parameters in common carp (Cyprinus carpio) larvae using probiotic in rearing tanks and feeding by various Artemia nauplii. AACL Bioflux, 4: 511-518.

Keysami, M. A., C.R. Saad, K. Sijam, H.M. Daud and A.R. Alimon (2007). Effcets of Bacillus subtilis on growth development and survival of larvae Macrobrachium rosenbergii (de Man). Aquac Nut, 13: 131-136.

Kumar, R., S.C. Mukherjee, K. Pani Prasad and A.K Pal (2006). Evaluation of bacillus subtilis as a probiotic to Indian major carp Labeo rohita (ham.). Aquac Res. 37:1215-1221.

Lara-Flores, M., M.A. Olvera-Novoa, B.E. GuzmanMendez and W. Lopez-Madrid (2003). Use of the bacteria Streptococcus faecium and Lactobacillus acidophilus and the yeast Saccharomyces cerevisiae as growth promoters in Nile tilapia (Oreochromis niloticus). Aquaculture. 216: 193-201.

Liu, C.H., C.S. Chiu, P.L. Lin and S.W. Wang (2009). Improvement in the growth performance of white shrimp, Litopenaeus vannamei, by a protease producing probiotic, Bacillus subtilis E20 from natto. J. of Appl Microbiol. 107: 1031-1041.

Liu, K.F., C.H. Chiu, Y.L. Shiu, W. Cheng and C.H. Liu (2010). Effects of the probiotic, Bacillus subtilis E20, on the survival, development, stress tolerance, and immune status of white shrimp, Litopenaeus vannamei larvae. Fish Shellfish Immun, 28: 837-844.

Macey, B.M. and V.E. Coyne (2005). Improved growth rate and disease resistance in farmed Haliotis midae through probiotic treatment. Aquaculture, 245: 249-26.

Merrifield. D. L., A. Dimitroglou, G. Bradley, R.T.M. Baker and S.J. David (2010). Probiotic applications for Rainbow trout (Oncorhynchus mykiss Walbaum) I. Effects on growth performance, feed utilization, intestinal microbiota and related health criteria. Aquacult. Nutr. 16: 504-510.

Mohapatra, S., T. Chakraborty, A.K. Prusty, P. Das, K. Paniprasad and K.N. Mohanta. 2012. Use of different microbial probiotics in the diet of rohu, Labeo rohita fingerlings; effects on growth, nutrient digestibility and retention, digestive enzyme activities and intestinal microflora. Aquacult. Nutr.18:1-11.

Nandi, A., G. Banerjee, S. Kumar D.K. Ghosh and A.K Ray (2017). Probiotic efficiency of Bacillus sp. in Labeo rohita challenged by Aeromonas hydrophila: assessment of stress profile, haemato-biochemical parameters and immune responses. J. Aquac Res. 48: 4334-4345.

Nayak, S.K (2010). Probiotics and immunity: a fish perspectives. Fish Shellfish Immunol. 29: 2-14.

[NRC] National Research Council (1993). Nutrient requirements of fish. [Washington DC: National Academy Press]. 124p.

Rachmawati, D., S. Istiyanto and M. Maizirwan (2017). Effect of phytase on growth performance, feed utilization efficiency and nutrient digestibility in Fingerlings of Chanos chanos (Forsskal 1775). Philipp. J. Sci. 146: 237-245.

Rick, W. and H.P. Stegbauer (1984). Alfa-amylase: measurement of reducing groups. (In: Methods of enzymatic analysis. $3^{\text {rd }}$ ) ed. Weinhein, Germany: Chemie Verlag p. 885-889.

Rengpipat, S., S. Rukpratanporn, S. Piyatiratitivorakul and P. Menasaveta (2000). Immunity enhancement in black tiger shrimp (Penaeus monodon) by a probiont bacterium (Bacillus S11). Aquaculture. 191: 271-288.

Sandeepa and Ammani (2015). Effect Of Probiotic Bacterium on Growth and Biochemical 
Parameters of Shrimp Litopenaeus vannamei. Int J. Recent Sci Res. 6: 2871-2875.

Salinas, I., A. Cuesta, M.Á. Esteban and J. Meseguer (2005). Dietary administration of Lactobacillus delbrüeckii and Bacillus subtilis, single or combined, on gilthead seabream cellular innate immune responses. Fish Shellfish Immunol, 19: 67-77.

Salinas, I., P. Díaz-Rosales, A. Cuesta, J. Meseguer, M. Chabrillón, M.Á. Morinigo and M.Á. Esteban (2006). Effect of heat-inactivated fish and nonfish derived probiotics on the innate immune parameters of a teleost fish (Sparus aurata L.). Vet Immunol Immunop. 111: 279-286.

Steel, R.G.D., J.H. Torrie and D.A. Dickey (1996). Principles and Procedures of Statistics 3rd ed (New York: McGraw Hill International Book Company, Inc)

Suzer, C., D. Çoban, H.O. Kamacı, S. Saka, K. Fırat, Ö. Otgucuoğlu and H. Küçüksarı (2008). Lactobacillus spp. bacteria as probiotics in gilthead sea bream (Sparus aurata, L.) larvae: effects on growth performance and digestive enzyme activities. Aquaculture. 280: 140-145.

Tacon, A.G. (1995). The Nutrition and Feeding of Farmed Fish and Shrimp-A Traning Mannual (FAO of The United Nations Brazil) pp 106109.

Taoka, Y., H. Maeda, J.Y. Jo, M.J. Jeon, S.C. Bai, W.J. Lee, K. Yuge and S. Koshio (2006). Growth, stress tolerance and non-specific immune response of Japanese flounder Paralichthys olivaceus to probiotics in a closed recirculating system. Fish Sci. 72: 310-321.Tawwab, M.A., M.A.A. Mousa and M. A. Mohammed (2010). Use of Live Baker's Yeast, Saccharomyces cerevisiae, in Practical Diet to Enhance the Growth Performance of Galilee Tilapia, Sarotherodon galilaeus (L.), and Its Resistance to Environmental Copper Toxicity. J World Aquac Soc. 41: 214-223.

Tawwab, M. A., M. A. A. Mousa and M. A. Mohammed. (2010). Use of Live Baker's Yeast, Saccharomyces cerevisiae, in Practical Diet to Enhance the Growth Performance of Galilee Tilapia, Sarotherodon galilaeus (L.), and Its Resistance to Environmental Copper Toxicity. Jurnal of The World Aquaculture Society, 41(S2):214-223.

Tovar-Ramírez, D., D. Mazurais, J.F. Gatesoupe, P. Quazuguel, C.L. Cahu, J.L. Zambonino-Infante (2010). Dietary probiotic live yeast modulates antioxidant enzyme activities and gene expression of sea bass (Dicentrarchus labrax) larvae. Aquaculture. 300:142-147.
Tseng, D.Y., P.L. Ho, S.Y.Huang, S.C. Cheng, Y.L. Shiu, C.S. Chiu, C.H. Liu (2009). Enhance-ment of immunity and disease resistance in the white shrimp, Litopenaeus vannamei, by the probiotic, Bacillus subtilis E20. Fish Shellfish Immunol. 26:339-344.

Verschuere, L., G. Rombaut, P. Sorgeloos and W. Verstraete, 2000. Probiotic bacteria as biological control agents in aquaculture. Microbiol Mol Biol Rev. 64: 655-671.

Wang, Y.B., Z. R. Xu and M. S. Xia (2005). The effectiveness of commercial probiotics in Northern White Shrimp (Penaeus vannamei L.) ponds, Fishery Science, 71, 1034-103.

Wang, Y.B. and Z.R. Xu (2006). Effect of probiotics for common carp (Cyprinus carpio) based on growth performance and digestive enzyme activities. Anim Feed Sci Tech. 127: 283-292.

Wang, Y.B., 2007. Effect of probiotics on growth performance and digestive enzyme activity of the shrimp Penaeus vannamei. Aquaculture. 269: 259-264.

Wang, Y.B., Z.Q. Tian, J.T. Yao, W.F. Li (2008a). Effect of probiotics, Enteroccus faecium, on tilapia (Oreochromis niloticus) growth performance and immune response. Aquaculture. 277: 203-207.

Wang, Y.B., J.R. Li, J. Lin (2008b). Probiotics in aquaculture: challenges and outlook. Aquaculture. 281:1-4.

Wen-Ying, S., F. Ling-Lin, I. Wei-Fen, Z. Yao-Rong (2010). Effect of dietary supplementation with Bacillus subtilis on growth, performance, immune response and antioxidant activities of the shrimp (Litopenaeus vannamei). Aquaculture Research, 41: 1691-1698.

Wu, Z.X., X.Feng, L.L. Xie, X.Y. Peng, J. Yuan and X.X. Chen (2012). Effect of Bacillus subtilis Ch9 for grass carp, Ctenopharyngodon idella (Valenciennes, 1844), on growth performance, digestive enzyme activities and intestinal microflora. J. Appl. Ichthyol. 28: 721-727.

Zhou, X.X., Y.B. Wang, and W.F. Li (2009). Effect of probiotic on larvae shrimp (Penaeus vannamei) based on water quality, survival rate and digestive enzyme activities. Aquaculture. 287:349-353.

Ziaei-Nejad, S., M.H. Rezaeib, G.A. Takami, D.L. Lovettd, A. Mirvaghefia, M. Shakourie (2006). The effect of Bacillus spp. bacteria used as probiotics on digestive enzyme activity, survival and growth in the Indian white shrimp Fenneropenaeus indicus. Aquaculture. 252: 516524. 